\title{
Increased risk of cognitive impairment and hyperglycemia-related mortality in late middle-aged African Americans with low serum adropin levels
}

Running title: Adropin correlations with cognition and mortality

\author{
Andrew A. Butler ${ }^{1,2,}{ }^{*}$, Geetika Agarwal ${ }^{3}$, Theodore K. Malmstrom ${ }^{2,4}$, Douglas K. Miller ${ }^{5}$, \\ Andrew D. Nguyen ${ }^{1,2,3}$, and John E. Morley ${ }^{3}$
}

1. Department of Pharmacology and Physiology, Saint Louis University School of Medicine, St. Louis, MO, USA.

2. Henry and Amelia Nasrallah Center for Neuroscience, Saint Louis University, St. Louis, MO, USA.

3. Division of Geriatric Medicine, Department of Internal Medicine, Saint Louis University School of Medicine, St. Louis, MO, USA.

4. Department of Psychiatry and Behavioral Neuroscience, Saint Louis University School of Medicine, St. Louis, MO, USA.

5. Regenstrief Institute, Inc., Indianapolis, IN, USA.

* Address correspondence to:

Professor Andrew A. Butler,

Department of Pharmacology and Physiology,

Saint Louis University School of Medicine,

St. Louis, MO, USA.

Email andrew.butler@health.slu.edu 


\begin{abstract}
Recent data implicate the secreted peptide adropin in the physiology of aging. In humans, adropin is highly expressed in brain tissues, and correlates positively with transcriptomic signatures of mitochondrial and synaptic functions. Adropin treatment improves performance of old mice in cognitive tests requiring learning and memory. While detected in the circulation of humans, no studies have investigated relationships between adropin, cognitive decline and aging. Here we compared serum adropin concentrations with Mini-Mental State Exam (MMSE) and animal naming test results from a cohort study of African Americans in late-middle age (baseline ages 49-65y, n=357). Using the lowest quintile of the MMSE to identify participants at risk for mild cognitive impairment (MCI) indicated lower serum concentrations $(2.95 \pm 1.32 \mathrm{ng} / \mathrm{ml}$ vs. $3.31 \pm 1.56, \mathrm{P}<0.05)$. Grouping into bins using $1-\mathrm{ng} / \mathrm{ml}$ increments in serum adropin concentrations further indicated an association between very low serum adropin concentrations and MCI. Using fructosamine as an indicator of moderate-term glucose levels suggested low serum adropin concentration correlate with increased risk of 10-year all-cause mortality in situations of poor glucose control. In summary, these data suggest low circulating adropin concentrations identify late-middle aged people at risk for cognitive impairment, and for all-cause mortality in situations of poor glucose control.
\end{abstract}

\title{
INTRODUCTION
}

Declining cognitive tasks involving information processing, working memory, flexibility in thinking, and self-control is considered a normal outcome of aging that can be accelerated by poorly controlled diabetes $(1 ; 2)$. Impaired memory and self-management of daily activities noticeable to the patient and caregivers but insufficient to require managed care is defined as mild-cognitive impairment (MCI) $(3 ; 4)$. MCI appears to represent the early stages of late-age onset dementias (LOAD), of which Alzheimer's disease is most prevalent(3; 4). An aging population indicates that managed care of people with LOAD will be a major health care challenge in the $21^{\text {st }}$ century. Treatment options for preventing LOAD or delaying its progression are however limited and controversial (5). Identifying biomarkers that identify elderly individuals at risk of LOAD and developing new treatment strategies to prevent or delay onset remains as a critical unmet need.

Adropin is a pleiotropic secreted peptide with endocrine, autocrine/paracrine and neuropeptide functions $(6$; 7). Adropin was originally identified as a hepatokine mediating homeostatic responses to variation in dietary macronutrient consumption (8). Subsequent studies suggest it is a stress-responsive hormone regulating glucose metabolism and insulin sensitivity in the liver (9-14), skeletal muscle (15; 16), and 
medRxiv preprint doi: https://doi.org/10.1101/2021.12.09.21267550; this version posted December 13, 2021. The copyright holder for this preprint (which was not certified by peer review) is the author/funder, who has granted medRxiv a license to display the preprint in perpetuity.

It is made available under a CC-BY-NC-ND 4.0 International license .

Adropin correlates with cognition and mortality

cardiac muscle (17-19). Circulating adropin concentrations in humans and nonhuman primates correlate with indices of glucose and cholesterol metabolism (20-24). Circulating adropin concentrations in nonhuman primates also correlate with endocrine and metabolic responses to an obesogenic (high sugar) diet (24). Adropin affects vascular tone by regulating endothelial nitric oxide synthase activity (25-27), and protecting against injury to the endothelium (28). Correlations with vascular endothelial function in humans have also been reported $(26 ; 29 ; 30)$. These results suggest adropin is an endocrine link between cellular stress responses and whole-body glucose and vascular homeostasis.

In humans, RNAseq datasets suggest adropin expression is most abundant in astrocytes residing in the central nervous system $(24 ; 31)$. An emerging literature indicates a role for adropin in neurological aging. Brain adropin expression correlates with gene networks implicated in mitochondrial function, cellular lipid metabolism, inflammation, synaptic plasticity, and vascular function(31). Adropin regulates the blood-brain barrier permeability and may preserve integrity during injury(32-34). Positive relationships are also observed with protein markers of tau-related neuropathology and inflammation in the old-old (age $>75 \mathrm{y}$ ), particularly in people who died without a dementia diagnosis(31). Brain adropin expression also exhibits an inverse relationship with cholesterol synthesis pathways(31). This is an intriguing observation, as plasma adropin and cholesterol concentrations are also negatively correlated(23). This relationship is thought to result from intermediates in cholesterol metabolism inhibiting adropin expression(23).

These physiological processes linked to adropin expression in the nervous system all relate to risk of MCI and $\operatorname{LOAD}(35 ; 36)$. Indeed, gene ontology analysis indicates relationships between expression of the adropin transcript and gene networks associated with neurodegenerative diseases in humans, nonhuman primates, and mice $(24 ; 31 ; 37)$. In preclinical mouse models of aging, adropin treatments have a positive impact on cognitive function. Transgenic over expression of adropin in male 18-month-old C57BL/6J (B6) mice, which corresponds to a human age of 56-69y(38), improves cognitive abilities related to spatial learning and memory and novel object recognition(31). Treatment of old B6 mice with synthetic peptide also reverses mild memory impairment observed in middle-aged mice(31). Adropin could thus have clinical potential both as a biomarker of brain health and as a lead for developing therapies against cognitive decline.

No studies on the relationship between serum adropin concentrations and aging have been reported. Here we analyzed serum adropin concentrations in the African American Health (AAH) study. AAH is a prospective analysis of disability and frailty amongst urban-dwelling African Americans over 10y (39). This ancillary study tested the hypothesis that low circulating levels of adropin indicate increased risk of MCI observed with aging. A secondary objective examined relationships between baseline adropin levels and indices of metabolic dysregulation. 
medRxiv preprint doi: https://doi.org/10.1101/2021.12.09.21267550; this version posted December 13, 2021. The copyright holder for this preprint (which was not certified by peer review) is the author/funder, who has granted medRxiv a license to display the preprint in perpetuity.

It is made available under a CC-BY-NC-ND 4.0 International license .

Adropin correlates with cognition and mortality

\section{RESEARCH DESIGN AND METHODS}

\section{Study participants}

All study procedures were approved by the Institutional Review Board at Saint Louis University and have therefore been performed in accordance with the ethical standards laid down in the 1964 Declaration of Helsinki and its later amendments. The African American Health cohort has been previously described (39; 40). Briefly, the study involved a population-based cohort of 998 self-identified African American individuals aged from 49 to 65 years at baseline. The study began in 2000-2001, and recruited residents in the St. Louis, Missouri metropolitan area. Participants completed in-home interviews and assessments at baseline followed by follow-ups at year 3 and year 9. Laboratory analyses used blood drawn for a subset of participants shortly after the in-home assessment, or during clinical examinations at baseline and 3-year follow-up. The final analytic sample for the current study includes 357 participants for which serum adropin concentrations were measured.

\section{MMSE and ANT tests}

The MMSE is used to detect cognitive deficits observed with dementia and delirium, and to measure changes in cognitive function over time(41). Scores of $\leq 23$ are $87 \%$ sensitive and $82 \%$ specific in detecting dementia and delirium using a psychiatrist's standardized clinical diagnosis as the criterion(42). One-minute naming tests such as the ANT assess memory recall and verbal fluency; an inability to name 15 or more suggests cognitive impairment and higher risk of dementia(43).

\section{Laboratory procedures}

Serum adropin concentrations were measured using an enzyme immunoassay kit from Phoenix Pharmaceuticals, Inc. (cat. no. EK-032-35) per manufacturers recommended protocol. Assays for the other serum measurements were described previously $(44 ; 45)$.

\section{Statistical analysis}

Data were analyzed using IBM SPSS Statistics version 19.0 (IBM Corp., Somers, NY). Adropin tertiles were defined by ranking all individuals by serum adropin low to high. Differences in the incidence of poor glucose control and mortality between adropin tertiles were assessed using chi-square tests. To adjust survival for age and sex, a value of ' 1 ' was used to indicate death and ' 0 ' indicated survival during the study (e.g., 40 deaths in a group of 100 would produce a mean of 0.4 , indicating $40 \%$ mortality). A similar approach was used to calculate the prevalence of poorly controlled glucose, with fructosamine values $>287 \mathrm{mmol} / \mathrm{L}$ assigned a value of ' 1 ' and normal values ' 0 '. For the analysis of the interaction between adropin and glucose control and 10-year mortality, fructosamine levels (high, normal) and 
medRxiv preprint doi: https://doi.org/10.1101/2021.12.09.21267550; this version posted December 13, 2021. The copyright holder for this preprint (which was not certified by peer review) is the author/funder, who has granted medRxiv a license to display the preprint in perpetuity.

It is made available under a CC-BY-NC-ND 4.0 International license .

Adropin correlates with cognition and mortality

adropin tertile were used as fixed variables. Estimated means were calculated adjusting for BMI, age, and sex as indicated.

\section{Data and resource availability}

The datasets generated during and/or analyzed during the current study are available from the corresponding author upon reasonable request.

\section{RESULTS}

AAH is comprised of "late middle-age" individuals with above average risk of depressive symptoms and disability $(39 ; 40 ; 46)$. Age, sex, and body mass index (BMI) of the 357 participates for which serum adropin concentrations were measured are shown in Table 1.

\section{Lower serum adropin concentrations in people with MCI}

The primary hypothesis is that low circulating adropin levels indicate increased risk of MCI. To address the hypothesis, baseline serum adropin concentrations were compared with baseline results from MiniMental State Exam (MMSE). Scores in the lowest quintile (MMSE_low_quint) were used to define study participants with poor cognitive function (Fig. 1).

The MMSE score for the MMSE_low_quint group ranged from 16 to 26, compared to 27-30 for the other study participants (Fig. 1A). Serum adropin concentrations were significantly lower in the MMSE_low_quint group compared to the rest of the cohort (Table 1). Sex-differences in circulating adropin concentrations have been reported previously(23). A 2-way ANOVA (fixed variables: sex, MMSE_low_quint) again identified a strong trend for effect of the latter (estimated marginal mean in $\mathrm{ng} / \mathrm{ml}$ and SEM of serum adropin concentrations for MMSE_low_quint, 2.94 \pm 0.19 , 95\%CI 2.575 to 3.30; compared to $3.34 \pm 0.10,95 \%$ CI 3.146 to $3.524, \mathrm{P}=0.059$ ), but no significant effect of sex (females, $3.14 \pm 0.13,95 \%$ CI 2.89 to 3.38 ; males, $3.14 \pm 0.17$, 95\% CI 2.81 to 3.47 ), with no interaction between sex and MMSE grouping.

These results were compared with outcomes from a second test of cognitive performance, the animal naming test (ANT). Participants in the lowest quintile (ANT_low_quint) were unable to name more than 13 animals (mean $\pm \mathrm{SD}$ and $95 \% \mathrm{CI} ; 11 \pm 2$ (4-13), range 4-13, $\mathrm{n}=51$ ) when compared to the upper other participants $(21 \pm 5$ (14-41), range 14-41, $\mathrm{n}=291, \mathrm{P}<0.001$ compared to ANT_low_quint). This group also exhibited a trend $(\mathrm{p}=0.081)$ for lower serum adropin concentrations $(2.97 \pm 1.35,(0.74-6.75)$ vs. $3.28 \pm 1.50$, (0.03-10.23).

Relationships between circulating adropin levels and indices known to signal risk of metabolic dysregulation (for example, age, obesity, fasting glucose, insulin, leptin, adiponectin, triglycerides) have 
medRxiv preprint doi: https://doi.org/10.1101/2021.12.09.21267550; this version posted December 13, 2021. The copyright holder for this preprint (which was not certified by peer review) is the author/funder, who has granted medRxiv a license to display the preprint in perpetuity.

It is made available under a CC-BY-NC-ND 4.0 International license .

Adropin correlates with cognition and mortality

been reported previously (20-24). Indices of metabolic homeostasis for which data are available (body mass index, age, adiponectin, leptin, and fructosamine) were not significantly different (Table 1). Adjusting for age and BMI in the analysis also did not change the outcome of the 2-way ANOVA. There was no evidence for metabolic dysregulation or inflammation in the ANT_low_quint group (data not shown).

We next used two approaches to further investigate whether high serum concentrations correlate with improved test scores in the MMSE and ANT. First, we ranked participants into tertiles by serum adropin concentrations (low, mid, high) (Table 2). Second, we separated participants into bins defined by $1 \mathrm{ng} / \mathrm{ml}$ increments in serum adropin concentrations (Fig. 1C, D). An advantage of using tertiles is a larger and consistent sample size ( $\mathrm{n}=119$ /tertile). However, using tertiles could miss non-linear relationships between serum concentrations and test scores observed with extremely low (or high) values.

Mean values for MMSE and ANT scores were not significantly different between tertiles (data not shown). Differences in baseline adropin concentrations between tertile also did not predict $10 \mathrm{y}$ changes in MMSE or ANT scores (data not shown). However, the distribution of MMSE_low_quint and ANT_low_quint scores between tertiles was consistent with high adropin levels reducing risk of cognitive impairment at baseline (Table 2). The highest tertile group exhibit 30\% fewer individuals in the low_quint scores. This group also had higher adiponectin and fructosamine, but lower triglycerides, compared to the lowest tertile (Table 2).

Serum adropin concentrations correlated with serum concentrations of adiponectin (positive), fructosamine (positive), and triglycerides (negative) (Table 2). Serum fructosamine concentrations are an independent predictor of incident diabetes and diabetes-related microvascular complications; levels exceeding $287 \mu \mathrm{mol} / \mathrm{L}$ indicate poorly controlled diabetes(47-49). Poorly control glucose homeostasis is also a strong predisposing risk factor for LOAD (2). In the current study participants with fructosamine values exceeding 287 had significantly higher serum adropin concentrations (3.59 $\pm 1.8,95 \%$ CI 3.23-3.94 $\mathrm{ng} / \mathrm{ml}$ vs. $3.16 \pm 0.09,2.99$ to $3.34 \mathrm{ng} / \mathrm{ml}, \mathrm{p}<0.036, \mathrm{n}=69$ vs. $\mathrm{n}=285)$.

Exploring the relationship between MMSE and ANT test scores and serum adropin concentration and bins in $1 \mathrm{ng} / \mathrm{ml}$ further indicated the positive relationship between serum adropin and cognitive performance. Performance in the MMSE was clearly compromised in participants with the lowest serum adropin values (effect of adropin bin for MMSE, P<0.05) (Fig. 2A). Adjusting for BMI and age did not affect the relationship (Fig. 2B). A similar relationship was observed between adropin bin and ANT scores (Fig. 2C, D) ( $\mathrm{P}=0.05)$. Analysis of other risk factors (indices of inflammation, metabolic homeostasis, sex steroids) failed to identify a defining variable (e.g., higher inflammation) explaining the correlation (Fig. 3). 
medRxiv preprint doi: https://doi.org/10.1101/2021.12.09.21267550; this version posted December 13, 2021. The copyright holder for this preprint (which was not certified by peer review) is the author/funder, who has granted medRxiv a license to display the preprint in perpetuity.

It is made available under a CC-BY-NC-ND 4.0 International license .

Adropin correlates with cognition and mortality

\section{Adropin predicts 10y mortality risk in late middle-aged people with poor glucose control}

Preclinical experiments using preclinical models suggest high adropin levels could be protective of cognitive decline in situations of metabolic dysregulation $(8-10 ; 15 ; 24 ; 31 ; 37)$. Here we observed an interaction between serum adropin concentrations and risk of all-cause mortality in study participants with poorly controlled glucose levels, indicated by fructosamine levels exceeding $287 \mu \mathrm{mol} / \mathrm{L}$ ( $\mathrm{n}=69$ ). The distribution of study participants with poorly controlled glucose appeared to be skewed between adropin tertiles (Fig. 4E) and was less frequently observed in the low tertile (17 of 119 participants) when compared to the high tertile (29 of 119). Incidence in study participants in the mid-tertile range was intermediate (23/119). However, risk of all-cause mortality exhibited the opposite relationship. Risk of all-cause mortality was increased 2 -fold in participants with fructosamine values $>287 \mu \mathrm{mol} / \mathrm{L}$ at baseline (Fig. 4A, B). While the prevalence of poorly controlled glucose homeostasis was increased in the tertile with high serum concentrations (Fig. 4E, Table 2). However, the relative risk of all-cause mortality was lower in this group compared to the lower adropin tertiles (Fig. 4E, F) (Table 3). Risk of all-cause mortality was comparable between adropin tertiles in the whole cohort (Fig. 4C, D).

\section{DISCUSSION}

The two major findings of this study indicate serum adropin concentrations are relevant to human aging. First, low circulating adropin concentrations correlate with increased risk of mild cognitive impairment in a late-middle aged cohort. Second, low circulating adropin concentrations could indicate increased risk for all-cause mortality for late-middle aged individuals with poorly controlled glucose.

A limitation of the current study is that it samples from a single geographic location and only included African Americans. However, if either or both relationships are observed in the general population, they could represent an important new metric for the clinical management of an aging population. Moreover, either or both could be amenable to pharmacological interventions using synthetic peptide mimetics to reverse a deficit in adropin activity.

Another limitation was that the AAH study used an MMSE of $<15$ as an exclusion criterion. The study population therefore excluded late-middle aged people with dementia. Future studies are needed to explore the relationships between circulating adropin concentrations and dementia. These studies could also screen for individuals with extremely low circulating adropin concentrations. The current study suggests that measuring circulating adropin concentrations could be a useful tool in characterizing cognitive functions in the elderly. However, further research is needed to characterize the individuals with very low levels. The use of circulating adropin concentration in defining subcategories of dementia, dementia diagnosis, and risk remains to be explored. 
A subset of the cohort had high fructosamine levels indicating poorly controlled glucose levels. In these individuals, low circulating adropin concentrations appeared to predict increased risk of all-cause mortality during the $10 \mathrm{y}$ study period. Given the small sample size, these findings should be viewed as preliminary. Further studies using larger sample sizes and cohorts that are more representative of the general population are needed. The study design should also allow for identifying specific causes of mortality indicated by low adropin levels.

Adropin could potentially affect mortality risk in situations of hyperglycemia through mechanisms involving vascular or metabolic homeostasis. Cardiovascular disease is the leading cause of death in people with elevated fasting glucose, although risk of microvascular complications is also increased(50). An emerging literature suggests adropin regulates vascular endothelial function $(25 ; 27 ; 32)$. Preclinical studies using mouse models also suggest adropin protects against stroke (34). On the other hand, adropin does not prevent the development of atherosclerosis in mouse models (23). Metabolically, adropin regulates the activities of the principal pancreatic hormones that control the fate of glucose and fatty acids. In the liver, adropin enhances insulin signaling $(10 ; 11)$ while suppressing glucagon signaling (9). Adropin also regulates insulin signaling and glucose metabolism in skeletal and cardiac muscle (15-17; 19). Clearly, further studies dissecting the association between circulating adropin concentrations and mortality risk in in situations of impaired glucose control are needed.

Further studies are also needed to determine whether circulating concentrations are a useful biomarker to identify middle-aged individuals at risk for LOAD. Investigation of the relationships between circulating adropin concentrations and cognitive functions in other age groups might also be informative. For example, adropin expression in the human brain peaks in the first decade of life, a critical period in brain development (31).

In the current study, serum adropin concentrations were elevated in people with poorly controlled glucose. This result is contradictory, as previous cross-sectional studies comparing groups with or without poorly control glucose reported the opposite(6). Furthermore, in a nonhuman primate model low plasma adropin concentrations correlated with fasting hyperglycemia (24). This discrepancy cannot be explained using the available data. However, it is worth noting that in humans the consumption of fructose beverages and associated insulin resistance increases plasma adropin concentrations, and that the magnitude of the response correlates with pre-existing markers of metabolic dysregulation (21). This observation could imply that circulating adropin levels can show an increase in the early stages of metabolic disease. Data from the current study also suggests that higher circulating adropin levels may protect individuals with poorly controlled glucose homeostasis from mortality and perhaps adverse effects. 
medRxiv preprint doi: https://doi.org/10.1101/2021.12.09.21267550; this version posted December 13, 2021. The copyright holder for this preprint (which was not certified by peer review) is the author/funder, who has granted medRxiv a license to display the preprint in perpetuity.

It is made available under a CC-BY-NC-ND 4.0 International license .

Adropin correlates with cognition and mortality

We have observed sex-specific differences in plasma adropin concentrations (23). The absence of sexeffect on serum adropin concentrations in the current study could be due to circulating adropin levels declining with age in men (23). On the other hand, other explanations are possible. These include differences in ethnicity, age, health, and socioeconomic status.

In summary, the results of the current study indicate that low circulating adropin concentrations in late middle-aged people associate with poor cognitive function, and for mortality risk in late-middle aged people with poorly controlled glucose. Further investigation is clearly indicated to determine whether the correlations observed in this cohort apply to the general population.

\section{ACKNOWLEDGEMENTS}

AAB was supported by the NINDS, NIH (R21NS108138). AAB and ADN acknowledge financial support provided by Saint Louis University. African American Health was supported by a grant from the National Institute on Aging (R01 AG010436 to DKM).

\section{Author contributions}

AAB was responsible for data management, data analysis, conceptual development, interpreting data, and preparation of the first draft of the manuscript. GA was responsible for provided data and preliminary data analysis. ADN provided resources and supervised data acquisition. TM was responsible for managing the complete AAH dataset, provided data, and assisted with analysis. DKM and JEM were responsible for conceptual development, design, and funding acquisition for the AAH study. All authors read and approved the manuscript for content. All authors read and approved the manuscript for content.

\section{Competing interest's statement}

The authors have no competing interests to report. 


\section{REFERENCES}

1. Murman DL: The Impact of Age on Cognition. Semin Hear 2015;36:111-121

2. Biessels GJ, Despa F: Cognitive decline and dementia in diabetes mellitus: mechanisms and clinical implications. Nat Rev Endocrinol 2018;14:591-604

3. Bradburn S, Murgatroyd C, Ray N: Neuroinflammation in mild cognitive impairment and Alzheimer's disease: A meta-analysis. Ageing Res Rev 2019;50:1-8

4. Chandra A, Valkimadi PE, Pagano G, Cousins O, Dervenoulas G, Politis M, Alzheimer's Disease Neuroimaging I: Applications of amyloid, tau, and neuroinflammation PET imaging to Alzheimer's disease and mild cognitive impairment. Hum Brain Mapp 2019;40:5424-5442

5. Liu KY, Howard R: Can we learn lessons from the FDA's approval of aducanumab? Nat Rev Neurol 2021;17:715-722

6. Butler AA, Havel PJ: Adropin and insulin resistance: Integration of endocrine, circadian, and stress signals regulating glucose metabolism. Obesity (Silver Spring) 2021;29:1799-1801

7. Mushala BAS, Scott I: Adropin: a hepatokine modulator of vascular function and cardiac fuel metabolism. Am J Physiol Heart Circ Physiol 2021;320:H238-H244

8. Kumar KG, Trevaskis JL, Lam DD, Sutton GM, Koza RA, Chouljenko VN, Kousoulas KG, Rogers PM, Kesterson RA, Thearle M, Ferrante AW, Jr., Mynatt RL, Burris TP, Dong JZ, Halem HA, Culler MD, Heisler LK, Stephens JM, Butler AA: Identification of adropin as a secreted factor linking dietary macronutrient intake with energy homeostasis and lipid metabolism. Cell metabolism 2008;8:468-481 9. Banerjee S, Ghoshal S, Stevens JR, McCommis KS, Gao S, Castro-Sepulveda M, Mizgier ML, Girardet C, Kumar KG, Galgani JE, Niehoff ML, Farr SA, Zhang J, Butler AA: Hepatocyte expression of the micropeptide adropin regulates the liver fasting response and is enhanced by caloric restriction. J Biol Chem 2020;295:13753-13768

10. Gao S, Ghoshal S, Zhang L, Stevens JR, McCommis KS, Finck BN, Lopaschuk GD, Butler AA: The peptide hormone adropin regulates signal transduction pathways controlling hepatic glucose metabolism in a mouse model of diet-induced obesity. J Biol Chem 2019;294:13366-13377

11. Chen X, Chen S, Shen T, Yang W, Chen Q, Zhang P, You Y, Sun X, Xu H, Tang Y, Mi J, Yang Y, Ling W: Adropin regulates hepatic glucose production via PP2A/AMPK pathway in insulin-resistant hepatocytes. FASEB J 2020;

12. Chen X, Sun X, Shen T, Chen Q, Chen S, Pang J, Mi J, Tang Y, You Y, Xu H, Ling W: Lower adropin expression is associated with oxidative stress and severity of nonalcoholic fatty liver disease. Free Radic Biol Med 2020;160:191-198

13. Chen X, Xue H, Fang W, Chen K, Chen S, Yang W, Shen T, Chen X, Zhang P, Ling W: Adropin protects against liver injury in nonalcoholic steatohepatitis via the Nrf2 mediated antioxidant capacity. Redox Biol 2019;21:101068

14. Thapa D, Xie B, Manning JR, Zhang M, Stoner MW, Huckestein BR, Edmunds LR, Zhang X, Dedousis NL, O'Doherty RM, Jurczak MJ, Scott I: Adropin reduces blood glucose levels in mice by limiting hepatic glucose production. Physiol Rep 2019;7:e14043

15. Gao S, McMillan RP, Zhu Q, Lopaschuk GD, Hulver MW, Butler AA: Therapeutic effects of adropin on glucose tolerance and substrate utilization in diet-induced obese mice with insulin resistance. Mol Metab 2015;4:310-324

16. Gao S, McMillan RP, Jacas J, Zhu Q, Li X, Kumar GK, Casals N, Hegardt FG, Robbins PD, Lopaschuk GD, Hulver MW, Butler AA: Regulation of substrate oxidation preferences in muscle by the peptide hormone adropin. Diabetes 2014;63:3242-3252

17. Altamimi TR, Gao S, Karwi QG, Fukushima A, Rawat S, Wagg CS, Zhang L, Lopaschuk GD: Adropin regulates cardiac energy metabolism and improves cardiac function and efficiency. Metabolism 2019;98:37-48

18. Thapa D, Xie B, Zhang M, Stoner MW, Manning JR, Huckestein BR, Edmunds LR, Mullett SJ, McTiernan CF, Wendell SG, Jurczak MJ, Scott I: Adropin treatment restores cardiac glucose oxidation in pre-diabetic obese mice. J Mol Cell Cardiol 2019; 
19. Thapa D, Stoner MW, Zhang M, Xie B, Manning JR, Guimaraes D, Shiva S, Jurczak MJ, Scott I: Adropin regulates pyruvate dehydrogenase in cardiac cells via a novel GPCR-MAPK-PDK4 signaling pathway. Redox Biol 2018;18:25-32

20. Butler AA, Tam CS, Stanhope KL, Wolfe BM, Ali MR, O'Keeffe M, St-Onge MP, Ravussin E, Havel PJ: Low circulating adropin concentrations with obesity and aging correlate with risk factors for metabolic disease and increase after gastric bypass surgery in humans. The Journal of clinical endocrinology and metabolism 2012;97:3783-3791

21. Butler AA, St-Onge MP, Siebert EA, Medici V, Stanhope KL, Havel PJ: Differential Responses of Plasma Adropin Concentrations To Dietary Glucose or Fructose Consumption In Humans. Sci Rep 2015;5:14691

22. Stevens JR, Kearney ML, St-Onge MP, Stanhope KL, Havel PJ, Kanaley JA, Thyfault JP, Weiss EP, Butler AA: Inverse association between carbohydrate consumption and plasma adropin concentrations in humans. Obesity (Silver Spring) 2016;24:1731-1740

23. Ghoshal S, Stevens JR, Billon C, Girardet C, Sitaula S, Leon AS, Rao DC, Skinner JS, Rankinen T, Bouchard C, Nunez MV, Stanhope KL, Howatt DA, Daugherty A, Zhang J, Schuelke M, Weiss EP, Coffey AR, Bennett BJ, Sethupathy P, Burris TP, Havel PJ, Butler AA: Adropin: An endocrine link between the biological clock and cholesterol homeostasis. Mol Metab 2018;8:51-64 24. Butler AA, Zhang J, Price CA, Stevens JR, Graham JL, Stanhope KL, King S, Krauss RM, Bremer AA, Havel PJ: Low plasma adropin concentrations increase risks of weight gain and metabolic dysregulation in response to a high-sugar diet in male nonhuman primates. J Biol Chem 2019;294:97069719

25. Lovren F, Pan Y, Quan A, Singh KK, Shukla PC, Gupta M, Al-Omran M, Teoh H, Verma S: Adropin is a novel regulator of endothelial function. Circulation 2010;122:S185-192

26. Fujie S, Hasegawa N, Kurihara T, Sanada K, Hamaoka T, Iemitsu M: Association between aerobic exercise training effects of serum adropin level, arterial stiffness, and adiposity in obese elderly adults. Appl Physiol Nutr Metab 2017;42:8-14

27. Fujie S, Hasegawa N, Horii N, Uchida M, Sanada K, Hamaoka T, Padilla J, Martinez-Lemus LA, Maeda S, Iemitsu M: Aerobic Exercise Restores Aging-Associated Reductions in Arterial Adropin Levels and Improves Adropin-Induced Nitric Oxide-Dependent Vasorelaxation. J Am Heart Assoc 2021:e020641

28. Dodd WS, Patel D, Lucke-Wold B, Hosaka K, Chalouhi N, Hoh BL: Adropin decreases endothelial monolayer permeability after cell-free hemoglobin exposure and reduces $\mathrm{MCP}$-1-induced macrophage transmigration. Biochem Biophys Res Commun 2021;582:105-110

29. Fujie S, Hasegawa N, Sato K, Fujita S, Sanada K, Hamaoka T, Iemitsu M: Aerobic exercise traininginduced changes in serum adropin level are associated with reduced arterial stiffness in middle-aged and older adults. Am J Physiol Heart Circ Physiol 2015;309:H1642-1647

30. Gozal D, Kheirandish-Gozal L, Bhattacharjee R, Molero-Ramirez H, Tan HL, Bandla HP: Circulating adropin concentrations in pediatric obstructive sleep apnea: potential relevance to endothelial function. The Journal of pediatrics 2013;163:1122-1126 31. Banerjee S, Ghoshal S, Girardet C, DeMars KM, Yang C, Niehoff ML, Nguyen AD, Jayanth P, Hoelscher BA, Xu F, Banks WA, Hansen KM, Zhang J, Candelario-Jalil E, Farr SA, Butler AA: Adropin correlates with aging-related neuropathology in humans and improves cognitive function in aging mice. NPJ Aging Mech Dis 2021;7:23

32. Yang C, DeMars KM, Candelario-Jalil E: Age-Dependent Decrease in Adropin is Associated with Reduced Levels of Endothelial Nitric Oxide Synthase and Increased Oxidative Stress in the Rat Brain. Aging Dis 2018;9:322-330

33. Yang C, DeMars KM, Hawkins KE, Candelario-Jalil E: Adropin reduces paracellular permeability of rat brain endothelial cells exposed to ischemia-like conditions. Peptides 2016;

34. Yang C, Lavayen BP, Liu L, Sanz BD, DeMars KM, Larochelle J, Pompilus M, Febo M, Sun Y-Y, Kuo Y-M, Mohamadzadeh M, Farr SA, Kuan C-Y, Butler AA, Candelario-Jalil E: Adropin confers neuroprotection and promotes functional recovery from ischemic stroke. BioRxiv (submitted); 
medRxiv preprint doi: https://doi.org/10.1101/2021.12.09.21267550; this version posted December 13, 2021. The copyright holder for this preprint (which was not certified by peer review) is the author/funder, who has granted medRxiv a license to display the preprint in perpetuity.

It is made available under a CC-BY-NC-ND 4.0 International license .

Adropin correlates with cognition and mortality

35. Frere S, Slutsky I: Alzheimer's Disease: From Firing Instability to Homeostasis Network Collapse. Neuron 2018;97:32-58

36. Nation DA, Sweeney MD, Montagne A, Sagare AP, D'Orazio LM, Pachicano M, Sepehrband F, Nelson AR, Buennagel DP, Harrington MG, Benzinger TLS, Fagan AM, Ringman JM, Schneider LS, Morris JC, Chui HC, Law M, Toga AW, Zlokovic BV: Blood-brain barrier breakdown is an early biomarker of human cognitive dysfunction. Nat Med 2019;25:270-276

37. Ghoshal S, Banerjee S, Zhang J, Niehoff M, Farr SA, Butler AA: Adropin transgenesis improves recognition memory in diet-induced obese LDLR-deficient C57BL/6J mice. Peptides 2021:170678 38. Flurkey K, Currer JM, Harrison DE: The Mouse in Aging Research. In The Mouse in Biomedical Research 2nd Edition Fox JG, Barthold SW, Davisson MT, Newcomer CE, Quimby FW, Smith AL, Eds., Elsevier, 2007

39. Miller DK, Wolinsky FD, Malmstrom TK, Andresen EM, Miller JP: Inner city, middle-aged African Americans have excess frank and subclinical disability. J Gerontol A Biol Sci Med Sci 2005;60:207-212 40. Miller DK, Malmstrom TK, Joshi S, Andresen EM, Morley JE, Wolinsky FD: Clinically relevant levels of depressive symptoms in community-dwelling middle-aged African Americans. J Am Geriatr Soc 2004;52:741-748

41. Cockrell JR, Folstein MF: Mini-Mental State Examination (MMSE). Psychopharmacol Bull 1988;24:689-692

42. Anthony JC, LeResche L, Niaz U, von Korff MR, Folstein MF: Limits of the 'Mini-Mental State' as a screening test for dementia and delirium among hospital patients. Psychol Med 1982;12:397-408 43. Canning SJ, Leach L, Stuss D, Ngo L, Black SE: Diagnostic utility of abbreviated fluency measures in Alzheimer disease and vascular dementia. Neurology 2004;62:556-562

44. Nguyen AD, Malmstrom TK, Niehoff ML, Aziz A, Miller DK, Morley JE: Serum progranulin levels are associated with frailty in middle-aged individuals. PLoS One 2020;15:e0238877

45. Haren MT, Banks WA, Perry Iii HM, Patrick P, Malmstrom TK, Miller DK, Morley JE: Predictors of serum testosterone and DHEAS in African-American men. Int J Androl 2008;31:50-59

46. Wolinsky FD, Miller DK, Andresen EM, Malmstrom TK, Miller JP: Health-related quality of life in middle-aged African Americans. J Gerontol B Psychol Sci Soc Sci 2004;59:S118-123

47. Cohen RM, Sacks DB: Comparing multiple measures of glycemia: how to transition from biomarker to diagnostic test? Clin Chem 2012;58:1615-1617

48. Selvin E, Rawlings AM, Grams M, Klein R, Sharrett AR, Steffes M, Coresh J: Fructosamine and glycated albumin for risk stratification and prediction of incident diabetes and microvascular complications: a prospective cohort analysis of the Atherosclerosis Risk in Communities (ARIC) study. Lancet Diabetes Endocrinol 2014;2:279-288

49. Malmstrom H, Walldius G, Grill V, Jungner I, Gudbjornsdottir S, Hammar N: Fructosamine is a useful indicator of hyperglycaemia and glucose control in clinical and epidemiological studies--crosssectional and longitudinal experience from the AMORIS cohort. PLoS One 2014;9:e111463

50. Yun JS, Ko SH: Current trends in epidemiology of cardiovascular disease and cardiovascular risk management in type 2 diabetes. Metabolism 2021;123:154838 
medRxiv preprint doi: https://doi.org/10.1101/2021.12.09.21267550; this version posted December 13, 2021. The copyright holder for this preprint (which was not certified by peer review) is the author/funder, who has granted medRxiv a license to display the preprint in perpetuity.

It is made available under a CC-BY-NC-ND 4.0 International license .

Adropin correlates with cognition and mortality

Table 1. Serum adropin concentrations in AAH study participants scoring in the lowest quintile for the MMSE at baseline compared to the rest of the cohort. Data shown are mean \pm std. dev and range (lowest value, highest value). N.S., not significantly different.

\begin{tabular}{|c|c|c|c|c|}
\hline & $\begin{array}{l}\text { All participants } \\
\text { (118 males, } 239 \\
\text { female) }\end{array}$ & $\begin{array}{l}\text { MMSE upper } 4 \text { quin. } \\
\text { (91 males, } 195 \\
\text { females) }\end{array}$ & $\begin{array}{l}\text { MMSE lowest quin. } \\
\begin{array}{c}(27 \text { males, } 44 \\
\text { females })\end{array}\end{array}$ & $P$ value \\
\hline \multicolumn{5}{|l|}{ Cognitive function } \\
\hline Mini-Mental State Exam & $28 \pm 3(16-30)$ & $29 \pm 1(27-30)$ & $24 \pm 2(16-26)$ & $\mathrm{P}<0.001$ \\
\hline Animal Naming Test & $19 \pm 6(4-41)$ & $20 \pm 6(8-41)$ & $16 \pm 6(4-38)$ & $\mathrm{P}<0.001$ \\
\hline Age (y) & $57 \pm 4(49-65)$ & $57 \pm 4(49-65)$ & $57 \pm 4(50-64)$ & N.S. \\
\hline BMI $\left(\mathrm{kg} / \mathrm{m}^{2}\right)$ & $31.4 \pm 7.0(14.5-55.7)$ & $31.6 \pm 6.8(15.7-55.7)$ & $30.8 \pm 7.5(14.5-48.4)$ & N.S. \\
\hline \multicolumn{5}{|l|}{ Blood chemistries } \\
\hline $\begin{array}{l}\text { Adropin } \\
\text { (ng/ml) }\end{array}$ & $\begin{array}{c}3.24 \pm 1.52 \\
(0.03-10.23)\end{array}$ & $\begin{array}{c}3.31 \pm 1.56 \\
(0.03-10.23)\end{array}$ & $\begin{array}{c}2.95 \pm 1.32 \\
(0.56-6.31)\end{array}$ & $\mathrm{P}<0.05$ \\
\hline $\begin{array}{l}\text { Leptin } \\
(\mathrm{ng} / \mathrm{ml})\end{array}$ & $\begin{array}{c}55 \pm 39 \\
(1-184)\end{array}$ & $\begin{array}{c}57 \pm 39 \\
(1-184)\end{array}$ & $\begin{array}{c}50 \pm 38 \\
(1-137)\end{array}$ & N.S. \\
\hline Adiponectin $(\mu \mathrm{g} / \mathrm{mL})$ & $\begin{array}{c}8.3 \pm 5.6 \\
(1.0-39.2)\end{array}$ & $\begin{array}{c}8.2 \pm 5.4 \\
(1.0-37.7)\end{array}$ & $\begin{array}{c}8.9 \pm 6.3 \\
(1.2-39.2)\end{array}$ & N.S. \\
\hline Fructosamine $(\mu \mathrm{mol} / \mathrm{L})$ & $\begin{array}{c}144 \pm 75 \\
(34-473)\end{array}$ & $\begin{array}{c}143 \pm 75 \\
(37-473)\end{array}$ & $\begin{array}{c}149 \pm 75 \\
(34-400)\end{array}$ & N.S. \\
\hline & $\begin{array}{c}266 \pm 65 \\
(104-577)\end{array}$ & $\begin{array}{c}265 \pm 64 \\
(104-577)\end{array}$ & $\begin{array}{c}269 \pm 66 \\
(176-501)\end{array}$ & N.S. \\
\hline
\end{tabular}


medRxiv preprint doi: https://doi.org/10.1101/2021.12.09.21267550; this version posted December 13, 2021. The copyright holder for this preprint (which was not certified by peer review) is the author/funder, who has granted medRxiv a license to display the preprint in perpetuity.

It is made available under a CC-BY-NC-ND 4.0 International license .

Adropin correlates with cognition and mortality

Table 2. Indices of MCI and metabolic homeostasis in study participants separated in tertiles ranked by serum adropin concentrations. Data shown are estimated marginal means \pm std. error $(95 \%$ confidence interval).

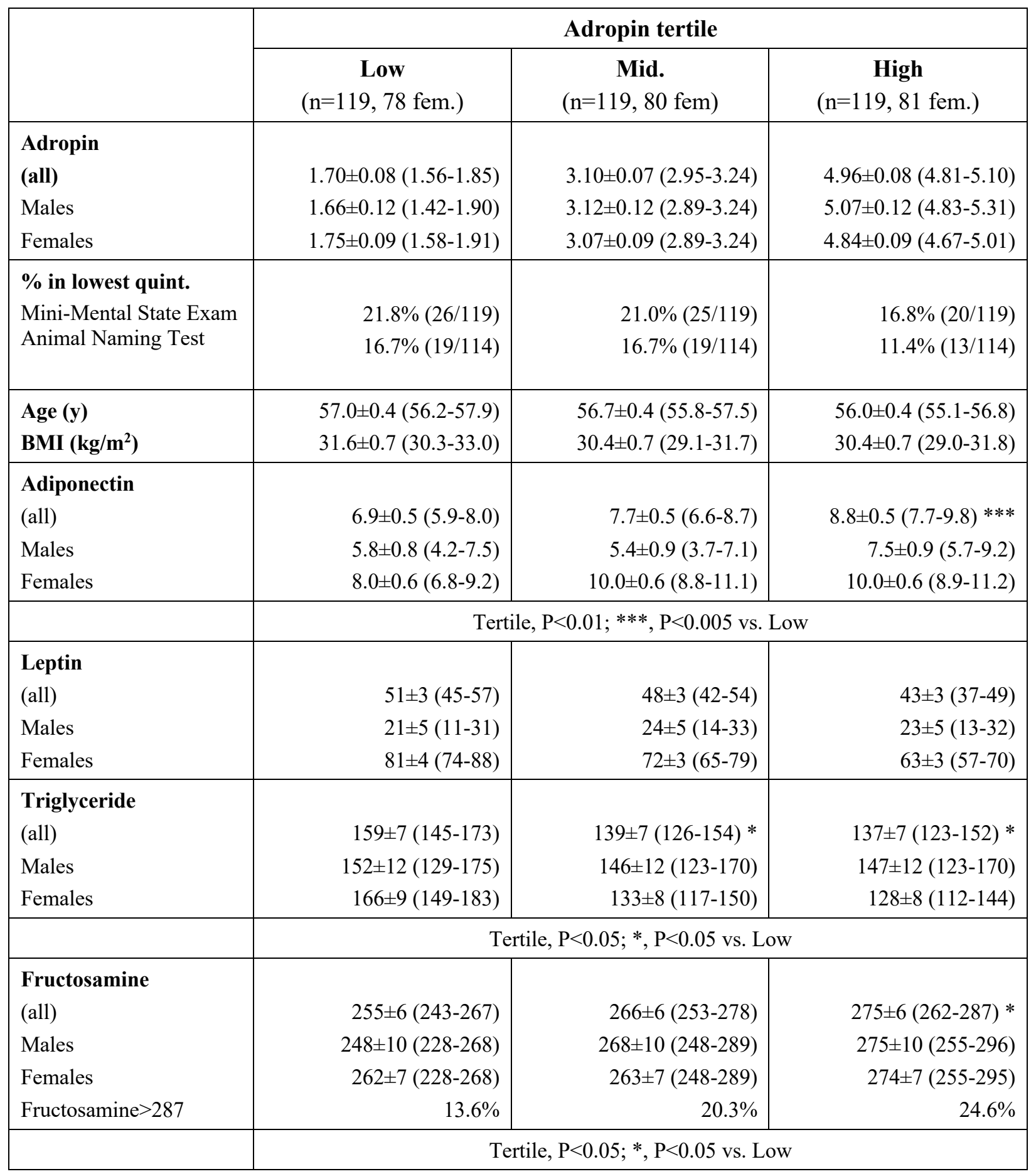


medRxiv preprint doi: https://doi.org/10.1101/2021.12.09.21267550; this version posted December 13, 2021. The copyright holder for this preprint (which was not certified by peer review) is the author/funder, who has granted medRxiv a license to display the preprint in perpetuity.

It is made available under a CC-BY-NC-ND 4.0 International license .

Adropin correlates with cognition and mortality

Table 3. Interaction between serum adropin concentrations and glucose regulation in 10-year mortality. Data show estimates of \%mortality (10y) in individuals with poorly controlled glucose homeostasis (fructosamine levels $>287 \mu \mathrm{mol} / \mathrm{L}, \mathrm{n}=69$ ) compared to individuals with fructosamine levels $<287(\mathrm{n}=285)$ during the AAH study. During the study, 97 participants died and 257 survived. Fructosamine data was not available for 3 study participants. Sample sizes and number of females (F) are indicated. Ranking for adropin tertile was based on the whole cohort.

\begin{tabular}{|c|c|c|c|c|}
\hline range & osamine & Adropin tertile & \%Mortality & $95 \% \mathrm{CI}$ \\
\hline \multirow{4}{*}{ Unadjusted } & $\begin{array}{r}\text { Normal } \\
\text { High }\end{array}$ & (all) & $\begin{array}{l}23 \% \\
51 \%\end{array}$ & $\begin{array}{l}18 \text { to } 28 \\
40 \text { to } 60\end{array}$ \\
\hline & (all) $(n=354)$ & $\begin{array}{l}1^{\text {st }}(\mathrm{n}=118,80 \mathrm{~F}) \\
2^{\text {nd }}(\mathrm{n}=118,79 \mathrm{~F}) \\
3^{\text {rd }}(\mathrm{n}=118,80 \mathrm{~F})\end{array}$ & $\begin{array}{l}46 \% \\
32 \% \\
32 \% \\
\end{array}$ & $\begin{array}{l}35 \text { to } 57 \\
22 \text { to } 42 \\
23 \text { to } 41\end{array}$ \\
\hline & $\begin{array}{l}\text { Normal } \\
(n=285)\end{array}$ & $\begin{array}{r}1^{\text {st }}(\mathrm{n}=101,66 \mathrm{~F}) \\
2^{\text {nd }}(\mathrm{n}=95,64 \mathrm{~F}) \\
3^{\text {rd }}(\mathrm{n}=89,61 \mathrm{~F})\end{array}$ & $\begin{array}{l}22 \% \\
20 \% \\
26 \%\end{array}$ & $\begin{array}{l}13 \text { to } 30 \\
11 \text { to } 29 \\
17 \text { to } 35\end{array}$ \\
\hline & High $(n=69)$ & $\begin{array}{l}1^{\text {st }}(\mathrm{n}=17,13 \mathrm{~F}) \\
2^{\text {nd }}(\mathrm{n}=23,14 \mathrm{~F}) \\
3^{\text {rd }}(\mathrm{n}=29,18 \mathrm{~F})\end{array}$ & $\begin{array}{l}71 \% \\
44 \% \\
38 \%\end{array}$ & $\begin{array}{l}50 \text { to } 91 \\
26 \text { to } 61 \\
22 \text { to } 54\end{array}$ \\
\hline \multirow{4}{*}{$\begin{array}{l}\text { Adjusted for age, } \\
\text { BMI, and sex. }\end{array}$} & $\begin{array}{r}\text { Normal } \\
\text { High }\end{array}$ & (all) & $\begin{array}{l}22 \% \\
48 \%\end{array}$ & $\begin{array}{l}17 \text { to } 28 \\
38 \text { to } 58\end{array}$ \\
\hline & (all) & $\begin{array}{l}1^{\text {st }} \\
2^{\text {nd }} \\
3^{\text {rd }}\end{array}$ & $\begin{array}{l}42 \% \\
32 \% \\
32 \%\end{array}$ & $\begin{array}{l}31 \text { to } 53 \\
22 \text { to } 41 \\
23 \text { to } 41\end{array}$ \\
\hline & Normal & $\begin{array}{l}1^{\text {st }} \\
2^{\text {nd }} \\
3^{\text {rd }}\end{array}$ & $\begin{array}{l}22 \% \\
20 \% \\
28 \% \\
\end{array}$ & $\begin{array}{l}14 \text { to } 30 \\
12 \text { to } 29 \\
19 \text { to } 37\end{array}$ \\
\hline & High & $\begin{array}{l}1^{\text {st }} \\
2^{\text {nd }} \\
3^{\text {rd }}\end{array}$ & $\begin{array}{l}63 \% \\
43 \% \\
36 \%\end{array}$ & $\begin{array}{l}42 \text { to } 83 \\
25 \text { to } 60 \\
21 \text { to } 52\end{array}$ \\
\hline
\end{tabular}


medRxiv preprint doi: https://doi.org/10.1101/2021.12.09.21267550; this version posted December 13, 2021. The copyright holder for this preprint (which was not certified by peer review) is the author/funder, who has granted medRxiv a license to display the preprint in perpetuity.

It is made available under a CC-BY-NC-ND 4.0 International license .

Adropin correlates with cognition and mortality

A

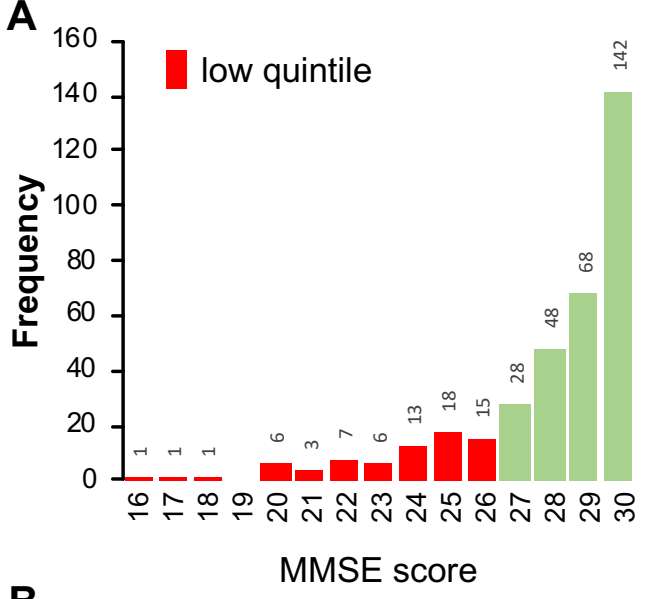

B

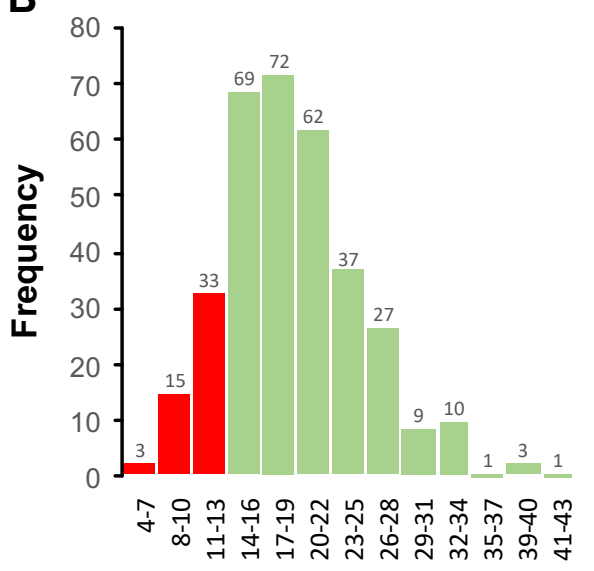

ANT score

C

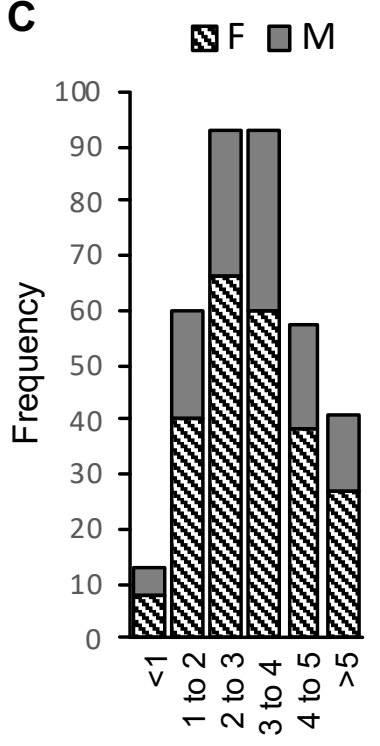

Bin range $(\mathrm{ng} / \mathrm{ml})$
D

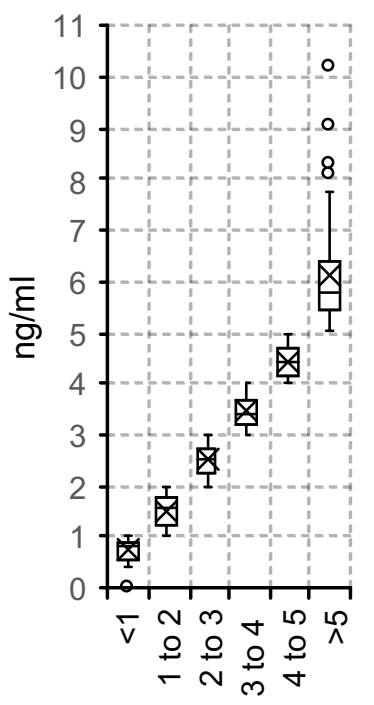

Bin range $(\mathrm{ng} / \mathrm{ml})$
Figure 1. Distribution of MMSE and ANT scores are shown (A, B). Sample size by sex (C) and serum adropin concentrations (D) for the cohort separated into $1 \mathrm{ng} / \mathrm{ml}$ bins. $\mathrm{M}$, male; F, female. 

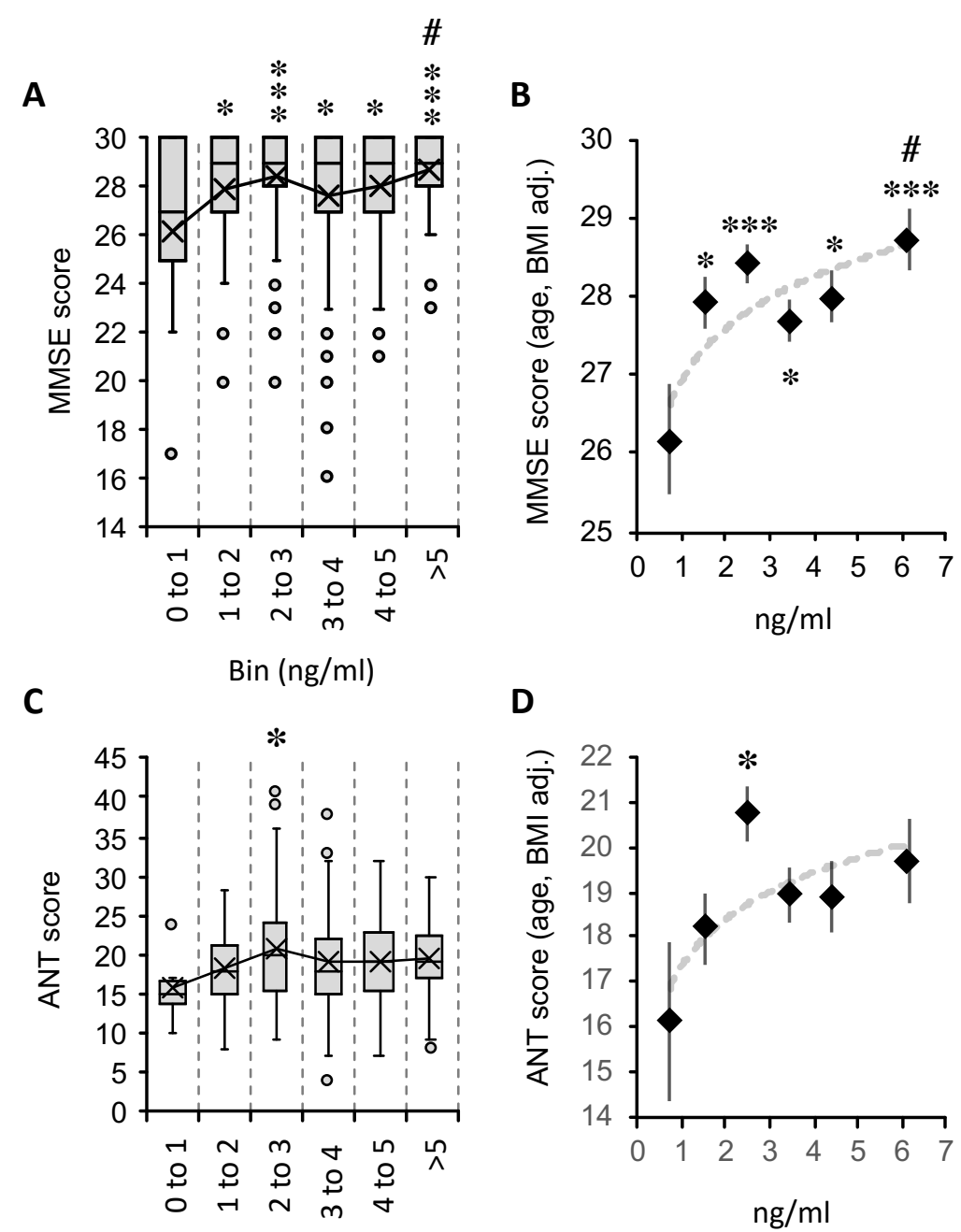

$\operatorname{Bin}(\mathrm{ng} / \mathrm{ml})$

Figure 2. Low serum adropin concentrations correlate with cognitive impairment in study participants grouped into bins of $1 \mathrm{ng} / \mathrm{ml}$ increments in serum adropin concentration. (A) Box and whisker plots of MMSE scores (B) MMSE scores adjusted for age and BMI plotted against serum adropin concentrations. Significance from 0 to $1 \mathrm{ng} / \mathrm{ml}$ bin determined by pairwise comparisons indicated by *** $(\mathrm{p}<0.005), *(\mathrm{p}<0.05)$; (C) Box and whisker plots of ANT scores. (D) ANT scores adjusted for age and BMI plotted against serum adropin concentrations between bins. *** $\mathrm{P}<0.005$ vs. $1 \mathrm{ng} / \mathrm{ml}$ bin; * <0.05 vs. $1 \mathrm{ng} / \mathrm{ml}$ bin; $\# \mathrm{P}<0.05$ vs. $3-4$ ng/ml bin. 
medRxiv preprint doi: https://doi.org/10.1101/2021.12.09.21267550; this version posted December 13, 2021. The copyright holder for this preprint (which was not certified by peer review) is the author/funder, who has granted medRxiv a license to display the preprint in perpetuity.

It is made available under a CC-BY-NC-ND 4.0 International license .

Adropin correlates with cognition and mortality

A

Inflammation/tissue injury markers

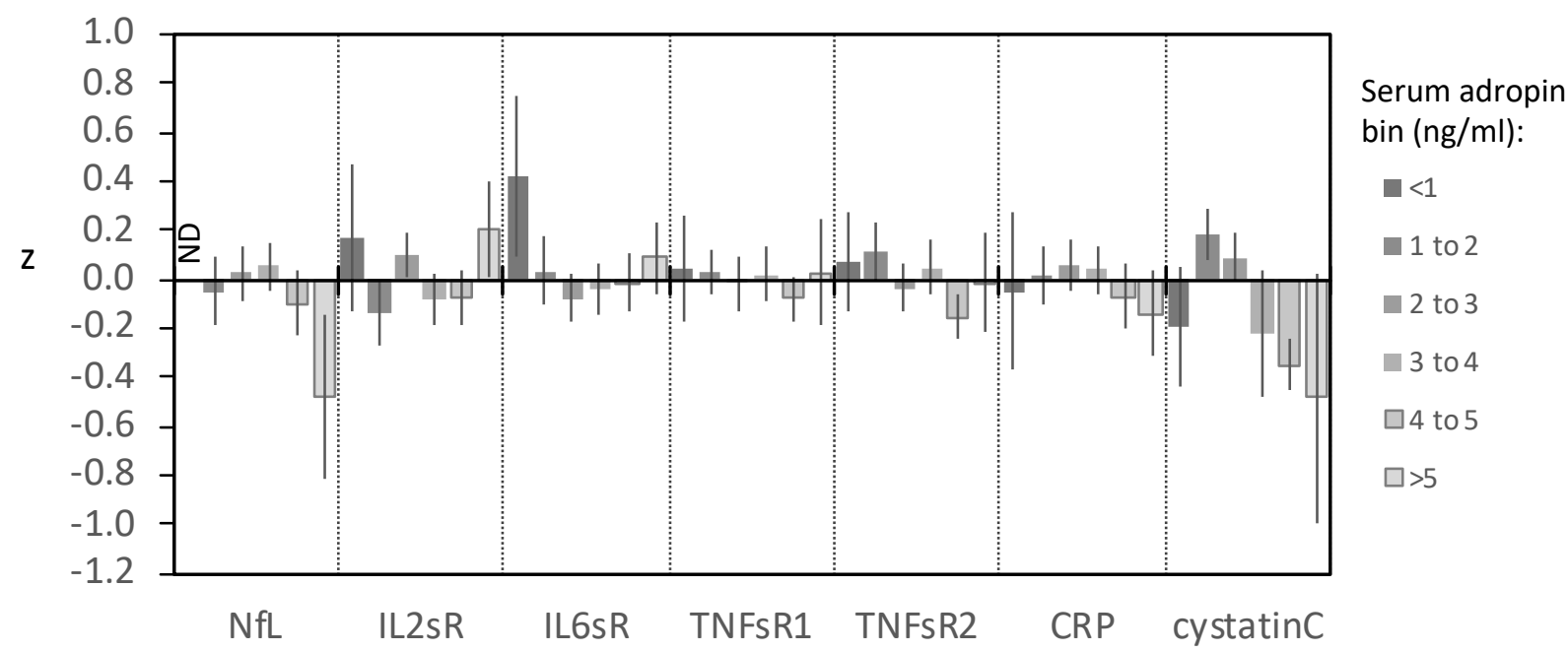

\section{B Gonadal function C Metabolic markers}
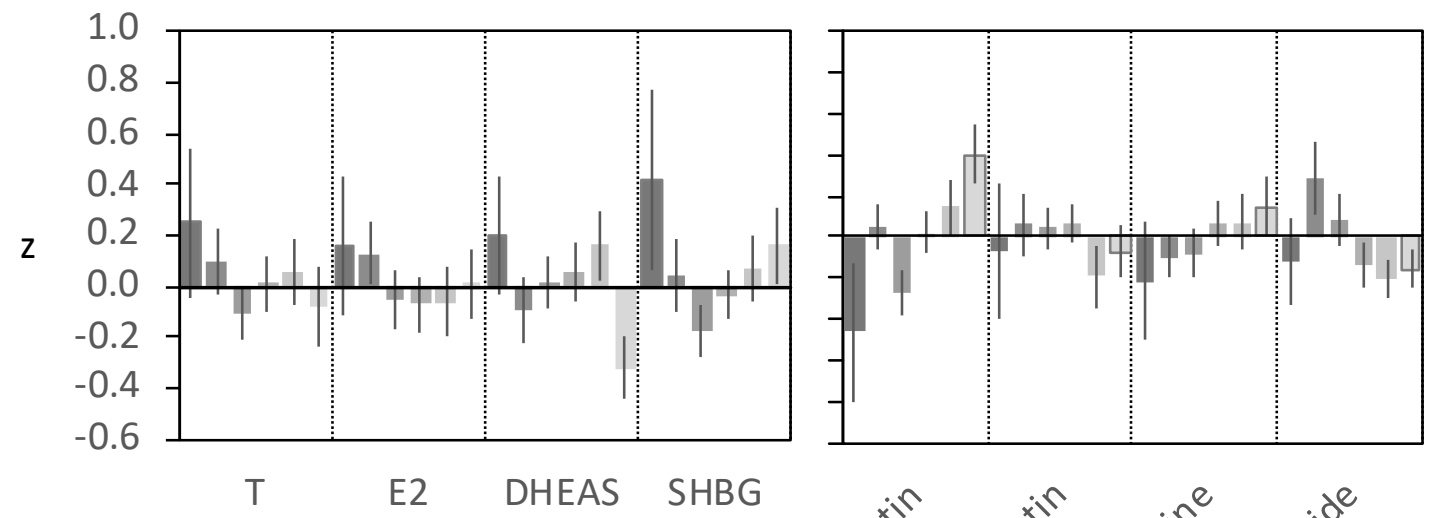

Figure. 3. Serum markers of inflammation and tissue injury (A), gonadotropic axis (B), and metabolic homeostasis $(C)$ for study participants separated into $1 \mathrm{ng} / \mathrm{ml}$ bins. The data shown are $\mathrm{z}$ scores. 
medRxiv preprint doi: https://doi.org/10.1101/2021.12.09.21267550; this version posted December 13, 2021. The copyright holder for this preprint (which was not certified by peer review) is the author/funder, who has granted medRxiv a license to display the preprint in perpetuity.

It is made available under a CC-BY-NC-ND 4.0 International license .

Adropin correlates with cognition and mortality

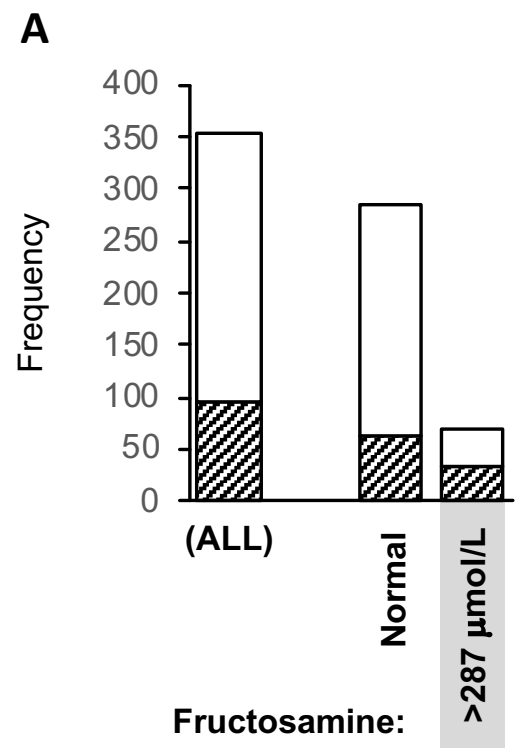

C

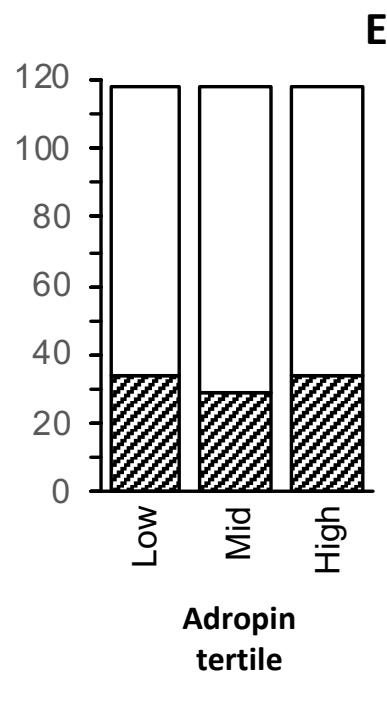

E Fatal event (10y):

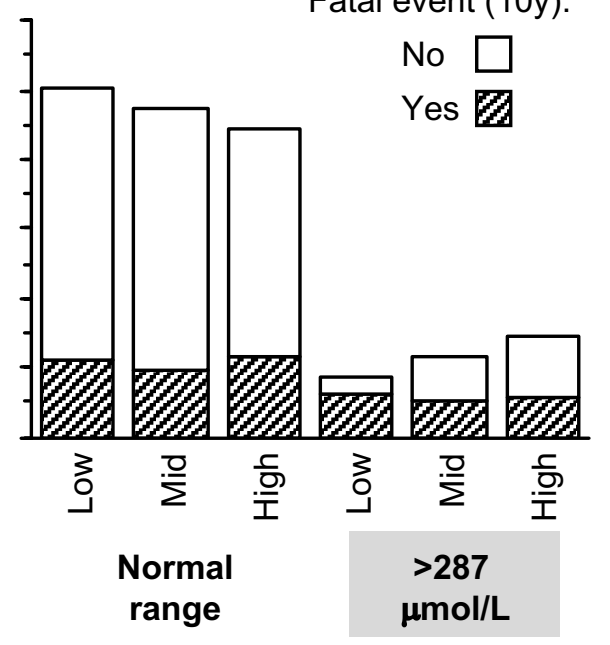

Fructosamine

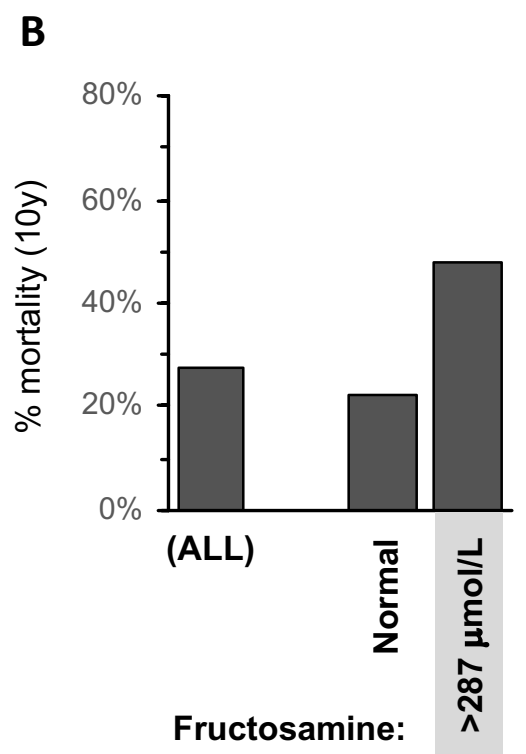

D

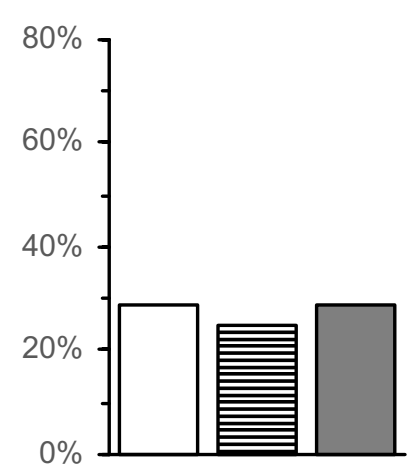

(ALL)
F $\quad$ Adropin tertile:

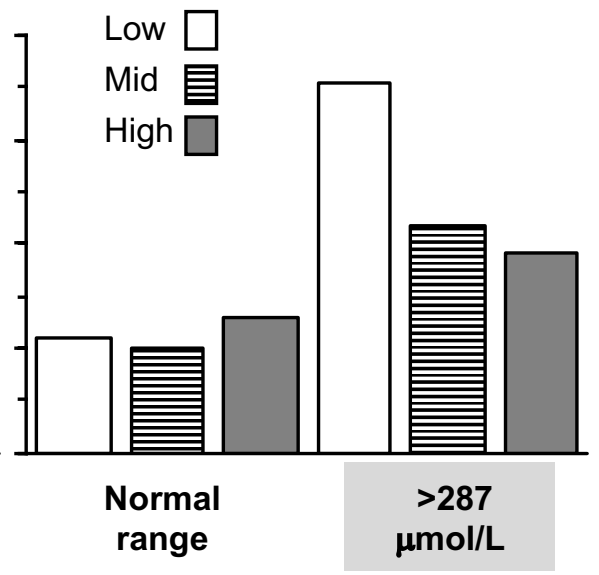

Fructosamine:

Figure 4. Increased risk of 10-year all-cause mortality in study participants with poorly controlled glucose (A, B) correlates with baseline serum adropin concentrations (C-F). Data shown are actual values $(A, C, E)$ and \%total $(B, D, F)$. Risk of mortality is two-fold higher with dysregulated glucose metabolism (A, B), indicated by fructosamine values $>287 \mu \mathrm{mol} / \mathrm{L}$. Mortality risk is similar between adropin tertiles in all participants $(\mathrm{C}, \mathrm{D})$, and in participants with normal fructosamine $(\mathrm{E}, \mathrm{F})$. However, while the incidence of poor glucose control increases with higher adropin levels, the risk of all-cause mortality declines. (E, F, P<0.005 using chisquare test). The dashed red reference line shows mortality risk for individuals with normal glucose control. Samples sizes are reported in Table 3. 